UDC 681.5

DOI: $10.25140 / 2411-5363-2020-3(21)-266-273$

\author{
Róbert Rákay, Alena Galajdová
}

\title{
TESTING PROPERTIES OF SMART CONDITON MONITORING SYSTEM
}

Urgency of the research. Modern trends in the automation focus on the implementation of new technologies to reduce production and maintenance costs. Maintenance and service of every industrial automation system is crucial.

Target setting. When engineers try to optimize the cost of production and processes, they usually reduce maintenance cost. The latest smart monitoring systems provide significant benefits in terms of risk management and equipment failure reduction.

Actual scientific researches and issues analysis. To prepare this paper, various publicly available datasheets and experimental solutions were analyzed as well as conclusions of other experiments were used to create the knowledge base on this research topic.

Uninvestigated parts of general matters defining. Many different monitoring technologies can operate online and offline from various vendors of automation technologies. This paper is insufficient to describe them all.

The research objective. In this article, automation monitoring systems were analyzed in terms of problems with machine inspection and predictive maintenance. And the results of the article form the basis for a further research task.

The statement of basic materials. To predict a future malfunction or to prevent the failure of an industrial machine now it is necessary to implement the latest monitoring technologies. The use of compact solutions in smart monitoring, such as Mitsubishi SCM or VIKON MMP, provides a good basis for solving problems such as bearing breakdowns and its subsequent failure.

Conclusions. The proposed paper provides possibilities for smart monitoring of an industrial automation system. The tested system can provide useful information about unknown conditions inside our device, without interrupting the operation.

Keywords: monitoring; maintenance; automation.

Fig.: 9. Table: 1. References: 9.

Introduction. The main goal of monitoring is to minimize the risk of failure by understanding the conditions by early fault detection. Failures can happen, but can be avoided. When a fault is triggered, the device loses power and a general degradation begins. With longer lasting defects the costs of intervention and consequences will increase with the risk of total device functional failure (Fig.1).

- Perfomance

a Risk/Cost

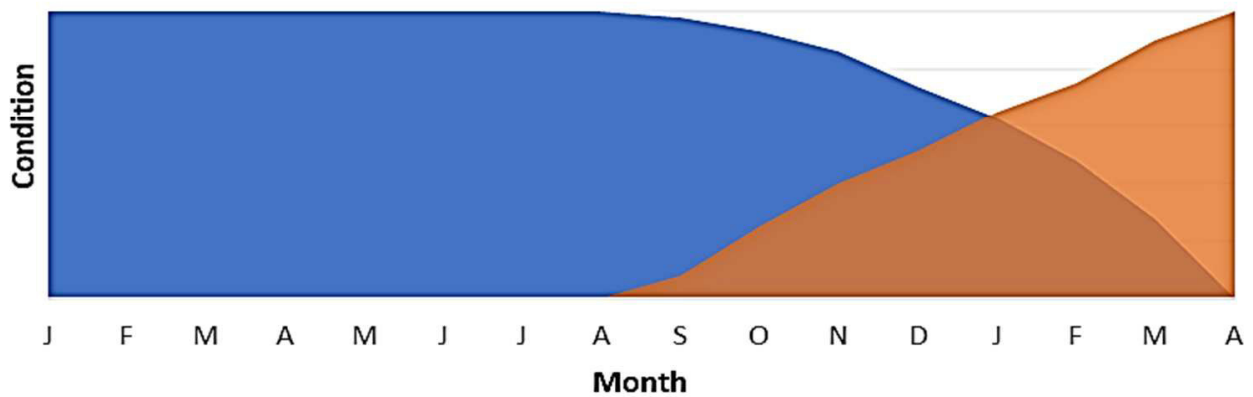

Fig. 1. Performance and Risk/Cost trends based on undetected defect occurrence

Together with real-time monitoring we can scan every part of a working device such as electric motor, rotor, stator, pump, pump rotors, bearing, gearbox etc. We use vibration to see inside the machine, to understand which component is degrading. Temperature measurement and ultrasound analysis are also standard methods for condition monitoring [1].

To increase the reliability of the performing device we must go beyond standard maintenance methods. These methods include elimination of unreliable suppliers, cheap spare parts, improper transportation, unskilled users, poor large scale design. In practice, inseparable steps in the maintenance of property are small-scale lubrication technology, high-quality spare parts and proper installation and operating procedures $[2,3]$.

The main function of the central processing unit in automated production systems include:

- Acquisition of production data (product type, number, time data).

- Activation of required component programs.

(c) Роберт Ракай, Альона Галайдова, 2020 
TECHNICAL SCIENCES AND TECHNOLOGIES

- System for exchange of information.

- Data exchange in the transport system.

- Data exchange in the measuring system.

- Representation of information for the user Continuous condition monitoring and diagnostics.

These functions are valid for modern devices and devices but, in the industrial area there are a large number of older machines that work continuously to this day. These devices also need to be monitored and diagnosed without interrupting their operation.

The main reasons for monitoring and diagnostics:

- Production systems and machine contain high value devices and parts, where there is a small defect or the error can cause large loss of production and damage on the machine.

- At high machine performance, the condition of the product, machine, or apparatus may change. A system with high level of automation produces a large amount of diagnostic data that cannot be monitored by human user alone.

Condition monitoring. The main goal of the monitoring system is to monitor the production machines and the system, to prevent damage to the machine tool and workpiece and to ensure the continuous operation. Monitoring can be devided to measurement, processing, decision and intervention. As main aspects of real-time condition monitoring, we must to ensure that this does not affect the speed of the system, and the system has to intervene before the actual damage has occurred. A monitoring system can be focused on a product (and its quality), device (or machine), tool or process (Fig.2).

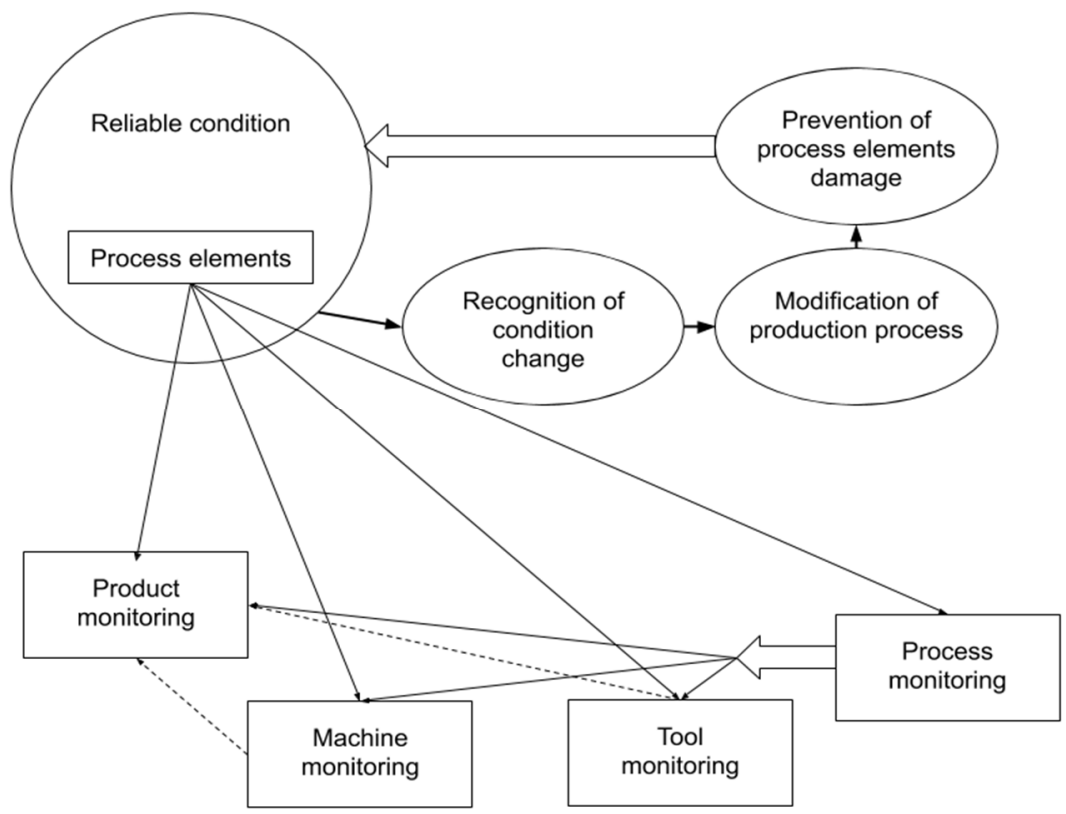

Fig. 2. Relation between monitoring systems

The monitored conditions can be divided into normal, specific, critical and dangerous conditions. The target is to keep the normal state. The particular status fulfils the technological requirements, but the harmful trend is measurable. The critical status is substantially different from normal, the process must be stopped and repaired. In the dangerous state is drastically different, immediate intervention is needed. Parameters are usually digital and analogue data, load, vibration and geometry data [3].

There are different monitoring technics for online and offline inspections. Load monitoring can be performed by force, torque, acoustic emission measurement, where the measured data are compared with the limit values for normal state values. 
Vibration monitoring. The vibration follows accessible parts of machines. The measurement can be analyzed in time or frequency domain.

Time domain analysis is less time consuming, graphically describes the conditions and does not provide comprehensive information about the system. Processing may include peak to peak or peak level measurements. For example, the analysis between the peak is useful at maximum stress, the average value determines the time course of the oscillating motion, the effective value (RMS - square root) is the most important part of the amplitude analysis. $[5,6]$

Frequency domain analysis. In real systems, the vibration signal is very complex. At the same time, there are different signals with different frequencies. The Fourier transform is used to separate the signal. Different parts of a device produce different vibration signal (Fig.3).

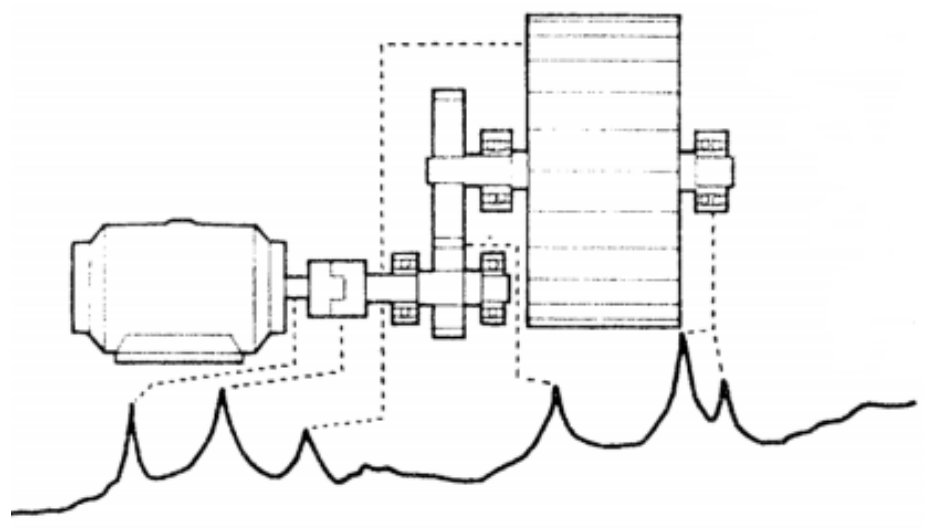

Fig. 3. Vibration signals of different machine parts

Because condition-based maintenance is often used only on the most critical equipments and systems, various vendors developed solutions that allow condition monitoring even in applications where it was not previously available. [4]

Vendors of automation technologies combine and use different technologies. Some technologies and solutions are listed below:

- Temperature measurement with or without direct contact,

- Revolution meters,

- Stray current detector,

- Endoscopes, stethoscopes,

- Noise level meters and ultrasound detectors,

- Vibration detectors etc. (Fig. 4).

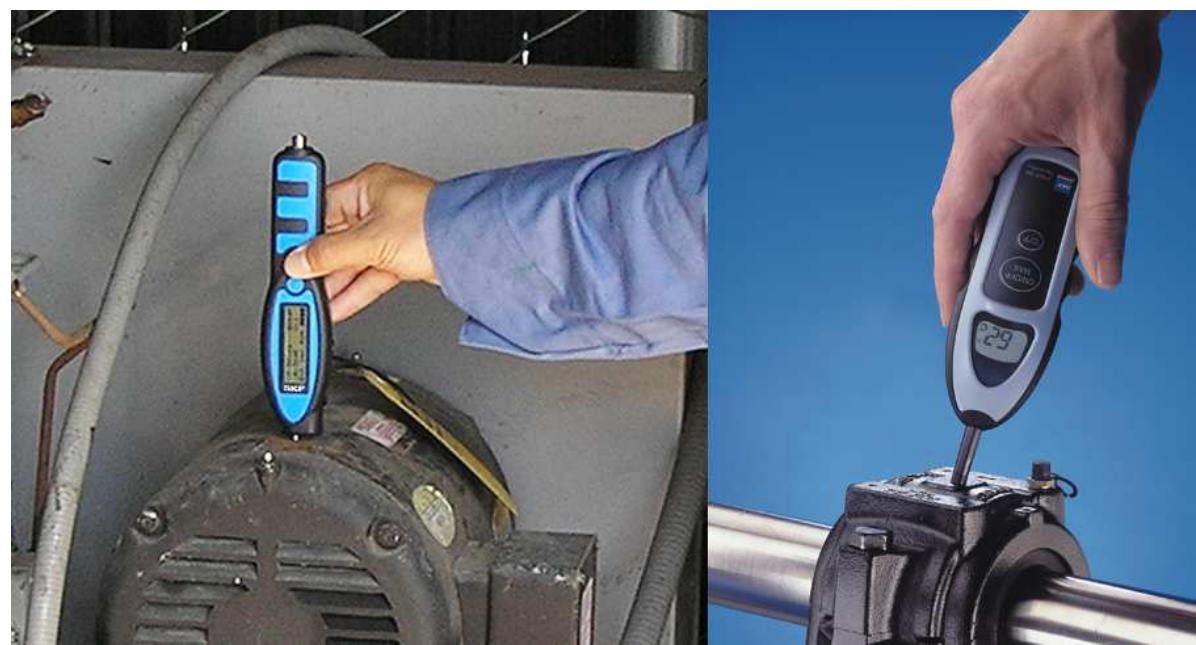

Fig. 4. Example condition measurement technologies 
TECHNICAL SCIENCES AND TECHNOLOGIES

These technologies are based on portable devices and the experience of maintenance users. These measurements are usually performed according to plan or when the device detect a fault.

The new level of condition monitoring is based on continuous devices monitoring. An example of such system is VIKON MMP, or MIVA Machine Protector. (Fig. 5) It combines a vibration alarm system with data collection unit. The device can work as separate unit or with connected PC and SW PEMAC for further evaluation and signal analysis [7].
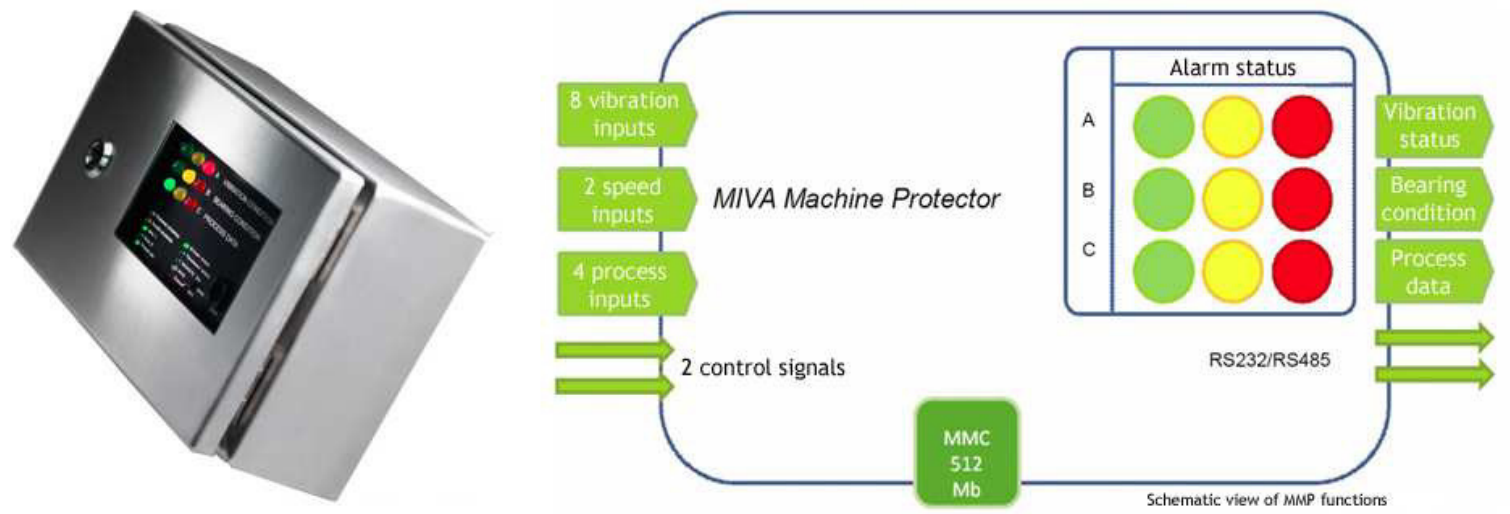

Fig. 5. VIKON monitoring system

Another example of the condition monitoring systems is Mitsubishi Smart Condition Monitoring or SCM KIT. (Fig. 6) It integrates the advanced FAG SmartCheck sensor with a powerful Mitsubishi PLC and HMI [8].

The system consists of: 1-PC station for commissioning, configuration and monitoring, 2 - Ethernet switch for interfacing the devices, 3 - SmartCheck sensor applied onsite, 4 - HMI panel as visualization and control panel, 5 - Programable logic controller for signal processing and automatic response.

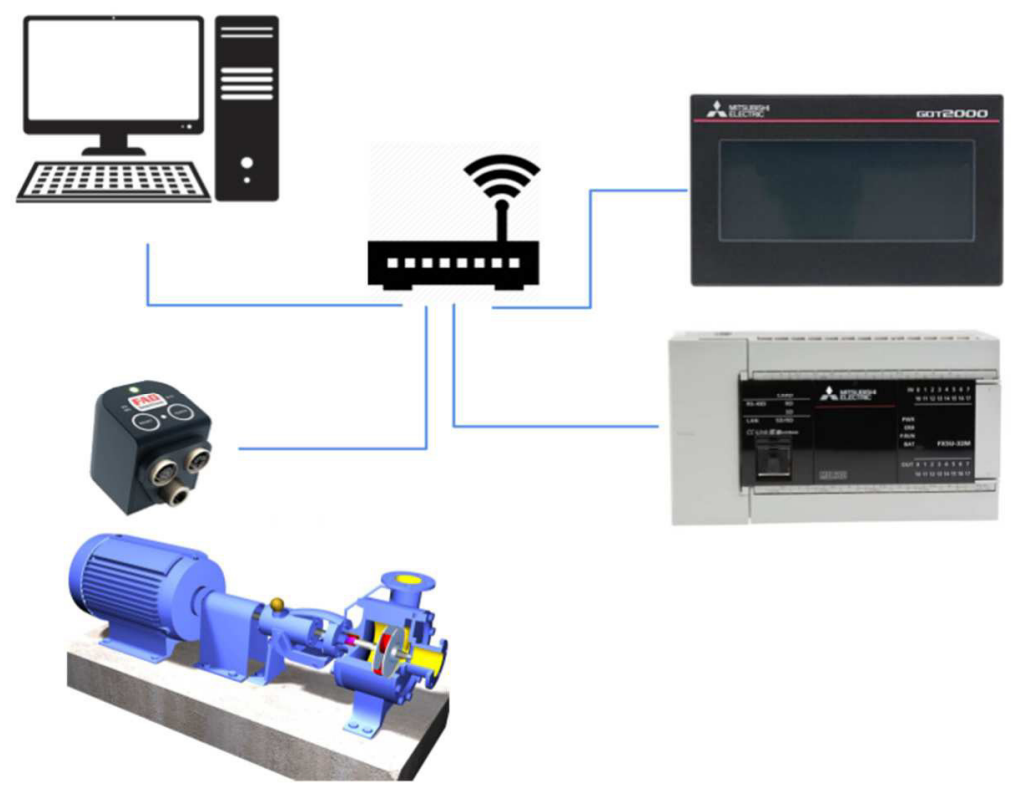

Fig. 6. Network of FAG SmartCheck and Mitsubishi devices [8]

The system includes templates to detect the following damages: rolling bearing damage, unbalance, misalignment, impacts. Monitoring can be carried out in three stages, based on the level of integration to the existing infrastructure. The first stage is a stand alone device, the second stage integrates the SmartCheck to the existing control system, while the third stage outsources external sensor security to the service provider [8].

The main technical data of the SmartCheck are described in the table below [9]. 
Table

Technical details of SmartCheck device [9]

\begin{tabular}{|c|c|}
\hline Vibration & $\begin{array}{l}\text { Acceleration sensor (piezoelectric sensor) } \\
\text { Frequency range: } 0.8 \mathrm{~Hz}-10 \mathrm{kHz} \\
\text { Measurement range: } \pm 50 \mathrm{~g}\end{array}$ \\
\hline Temperature & Measurement range: -20 to $+70^{\circ} \mathrm{C}$ \\
\hline Measurement functions & $\begin{array}{c}\text { Acceleration } \\
\text { Speed and path by integration } \\
\text { System temperature } \\
\text { Process parameters (e.g. speed, load, pressure) }\end{array}$ \\
\hline Diagnostic methods & Time signal, demodulation, spectrum and trend analysis, speed and frequency tracking \\
\hline $\begin{array}{l}\text { Calculated characteristic } \\
\text { values }\end{array}$ & $\begin{array}{c}\text { RMS, frequency-selective RMS, constant component, peak, peak-to-peak, crest factor, } \\
\text { Wellhausen count, carpet level, condition guard } \\
\text { Other user-defined characteristic values are possible. }\end{array}$ \\
\hline Frequency resolution & $\begin{array}{c}1600,3200,6400 \text { or } 12800 \text { lines Min. line width } 0.0039 \mathrm{~Hz} \text { at } 50 \mathrm{~Hz} \text { (depending on } \\
\text { low-pass) }\end{array}$ \\
\hline Measurement resolution & 24 bit (A/D converter) \\
\hline Power consumption & $<200 \mathrm{~mA}$ at $24 \mathrm{~V}$ \\
\hline Communication & /s; RS485 (current \\
\hline
\end{tabular}

The device can be configured using 3 software: FAG SmartWeb, FAG SmartUtility light or FAG SmartUtility. FAG SmartWeb is a web interface for direct access. FAG SmartUtility light is free and allows you to use several devices with one software, while the paid version FAG SmartUtility is suitable for central management of production machines at all sites or for data analysis.

By default, FAG SmartCheck uses preset alarm thresholds. The operating vibrations in a machine are decisively influenced by the specific operating condition. The FAG SmartCheck has an automatic learning mode to set the alarm thresholds to match the specific device. During commissioning the learning mode sets the threshold values [9].

For demonstration purposes a model of industrial production system was used, precisely its conveyor belt motors. Measured data are visualized in web application FAG SmartWeb (Fig. 7) live measurement is available in this application, and device configuration is also performed.

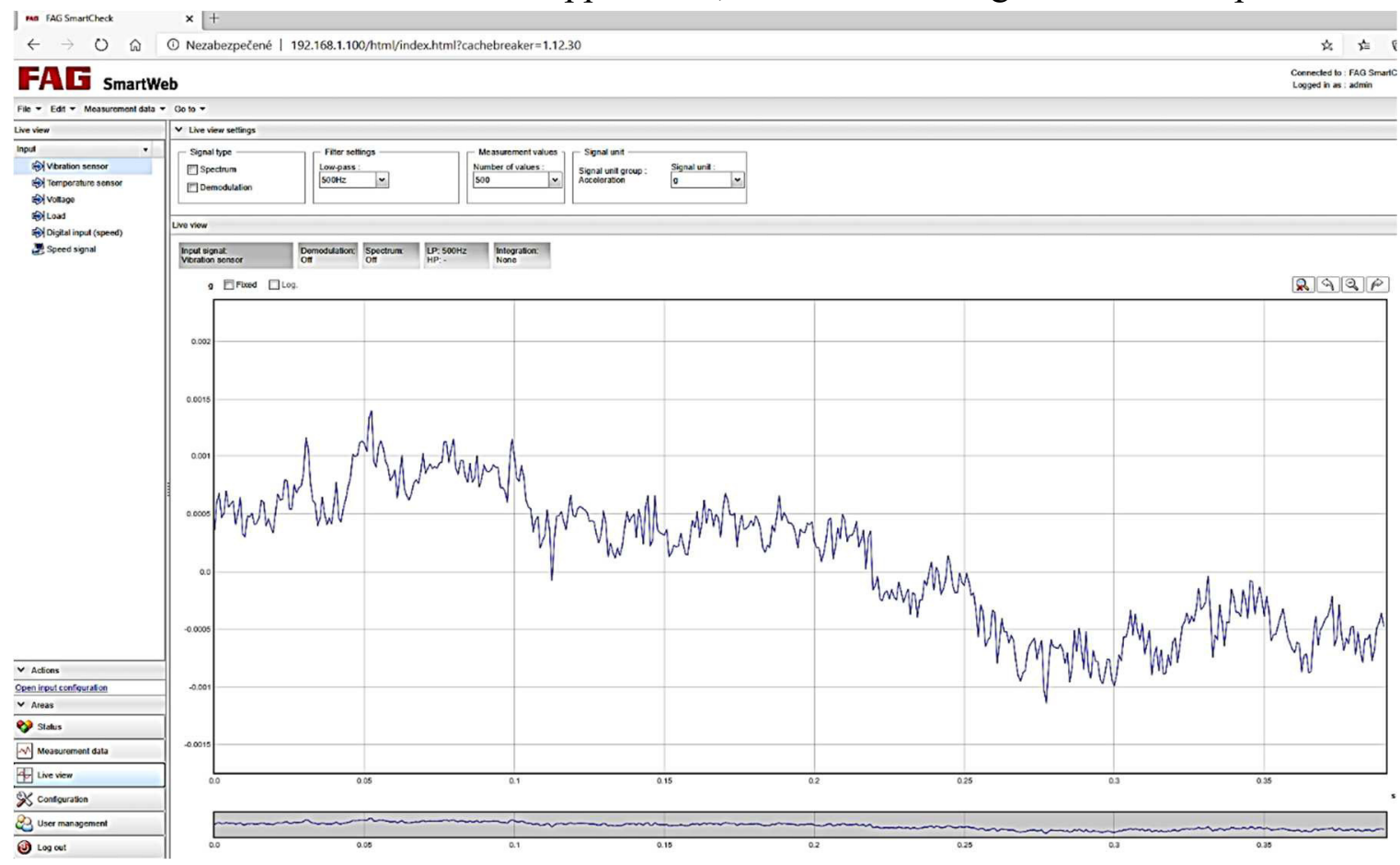

Fig. 7. SmartWeb - web interface 
TECHNICAL SCIENCES AND TECHNOLOGIES

Other option of accessing and use of data is with PLC (programmable logic controller) and a connected HMI (human machine interface). The below listed hardware was used in our KIT:

- PLC-Mitsubishi FX5U-32M

- HMI- Mitsubishi GT2104-RTBD

- Power Supply -PSU25

- Industrial unmanaged Gigabit PoE Ethernet switch - ORing- IGPS- 1080-24V

The demonstration measurements resulted a significant difference between the two analyzed conveyor motors.
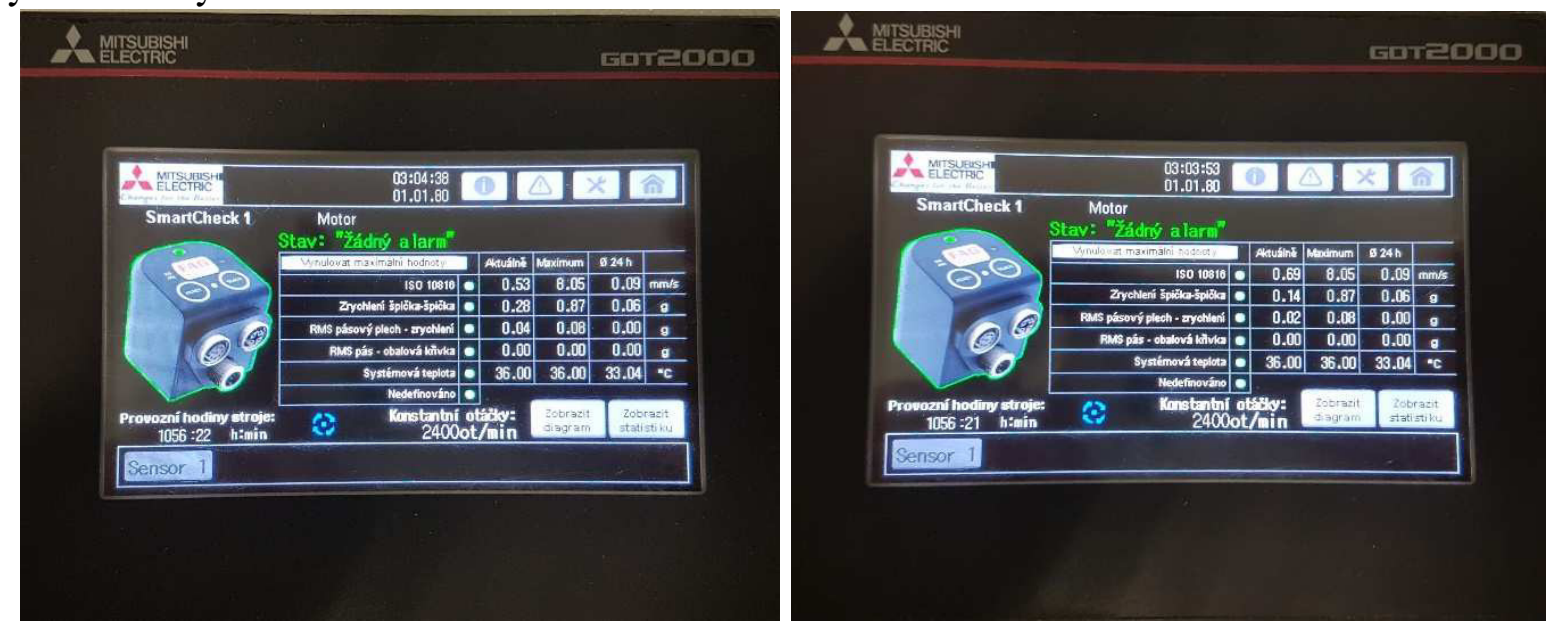

Fig. 8. HMI of Motor 1 and Motor 2 measurements

The HMI panel showed difference during the measurement of ISO 10816 -Mechanical vibration. Fig. 8 displays difference of actual states. Due to time constraints the experiment had to be carried out only for a short time. The long term and maximal values were not affected by our measurements. Further experimentation will be aimed on longer monitoring.

While all the relevant data can be shown on the HMI of the Smart KIT, for more detailed view and configuration the web interface is more suitable.

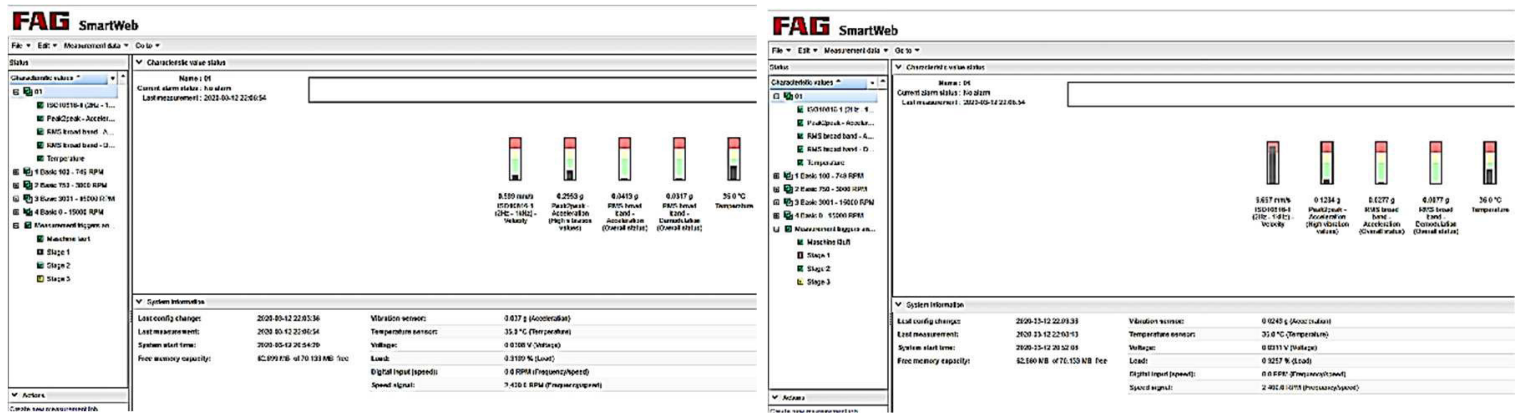

Fig. 9. Web interface of Motor 1 and Motor 2 measurements

While the first conveyor motor did not show any failure, the second motor caused mechanical vibration. This difference is visible on Fig.9, of ISO 10816-1. This measurement can provide basis for further system analysis.

In terms of time, we were not able to perform more tests on the conveyor system. Further tests and analysis will be performed on the laboratory production system in the future.

With this Smart Condition Monitoring KIT, it is not necessary to analyze separately the data, the software tool is charged for this purpose and requires expertise in signal analysis. However, the system can use the automatic learning function to detect the normal "behaviour" of the system and then detect the fault, when it occurs. 
Conclusion. This paper describes, automation production monitoring systems. The modern smart monitoring systems are unique in the concept of implementation and operations because there is not necessary to interrupt production or process and it is possible to inspect different components of assets. Smart monitoring system as Mitsubishi SCM or VIKON MMP will find application in the maintenance and monitoring tasks of existing devices. The integrated smart sensor can be used as an intelligent tool via outsourced service. In the experimental part two conveyor motors were analyzed using the FAG SmartCheck system. Various configuration templates are available in the online training mode for successful system setup This training mode requires several hours of continuous operation which was currently not possible.

Finally, the carried-out experiments have shown that Mitsubishi SCM is suitable for standalone condition monitoring tasks and for integration into existing production systems. Thanks to simplified visualization and web application it's not necessary to understand every small aspect of the issue of processing special diagnostics signal.

Acknowledgement. This work has been supported by the Slovak Grant VEGA 1/0330/19 Výskum a návrh algoritmov a systémov pre fúziu rôznorodých dát v multisenzorových architektúrach.

\section{References}

1. VAGAŠ,M.- GALAJDOVÁ, A. - ŠIMŠÍK, D. Nasadenie bezkontaktných ochranných zariadení do automatizovaných pracovísk, ARTEP 2020. Košice (Slovensko) : Technická univerzita v Košiciach pp. 1-6 . ISBN 978-80-553-3487-5.

2. VAGAŠ, M. - S̆IMŠÍK, D. - GALAJDOVÁ, A. - ONOFREJOVÁ, D. Safety as necessary aspect of automated systems ICETA 2018 : Proceedings : 16th IEEE International Conference on Emerging eLearning Technologies and Applications. - New Jersey (USA) : Institute of Electrical and Electronics Engineers s. 617-622 [print]. - ISBN 978-1-5386-7912-8.

3. VAGAŠ,M.- Automated and robotized workplaces based on industry 4.0 with focus to safety issues, Interdisciplinarity in Theory and Practice : the Journal for Presentation of Interdisciplinary Approaches in Various Fields. - Arad (Rumunsko) : Adoram č. 18 (2019), s. 1-5 [print]. - ISSN 2344-2409.

4. COX.J Vibration Pen, Shock Pulse Measurement (SPM), \& Vibration Analysis - What's the Difference? Available from: http://www.maintenanceworld.com/vibration-pen-shock-pulsemeasurement-spm-vibration-analysis-whats-the-difference/.

5. VAGAŠ,M.- ŠIMŠÍK, D. -ONOFREJOVÁ,D. Faktory úspešného nasadenia automatizovaných riešení v kontexte priemyslu 4.0, Atp journal : priemyselná automatizácia a informatika : odborný mesačník o priemyselnej automatizácii, informatike a robotike. - Bratislava (Slovensko) : HMH 26(5), pp. 56-58. 2019[print]. - ISSN 1335-2237.

6. D'Emilia, G. - Gaspari, A. - Natale, A. Integration of model and sensor data for smart condition monitoring in mechatronic devices, 2019 II Workshop on Metrology for Industry 4.0 and IoT (MetroInd4.0\&IoT), Naples, Italy, 2019, pp. 365-370, doi: 10.1109/METROI4.2019.8792908.

7. VIKON MIVA Machine Protector MMP [online] Available from: http://www.vikon.se/produkter.php?inc=mivammp.

8. Mitsubishi Electric Smart Condition Monitoring [online] Available from: https://www.koningenhartman.n1/UserFiles/Product/Brochure/SCM\%20Flyer.pdf.

9. FAG SmartCheck Machinery monitoring for every machine [online] Available from: https://www.schaeffler.com/remotemedien/media/_shared_media/08_media_library/01_publications/s chaeffler_2/tpi/downloads_8/tpi_214_en_us.pdf.

УДК 681.5

\section{Роберт Ракай, Алена Галайдова \\ ТЕСТУВАННЯ ВЛАСТИВОСТЕЙ РОЗУМНОЇ СИСТЕМИ МОНІТОРИНГУ СТАНУ}

Актуальність теми дослідження. Сучасні тендениії в автоматизаџї орієнтовані на впровадження нових технологій для зниження витрат на виробництво й обслуговування. Утримання та обслуговування кожной системи промислової автоматизації має вирішальне значення. 


\section{TECHNICAL SCIENCES AND TECHNOLOGIES}

Постановка проблеми. Коли інженери намагаються оптимізувати вартість виробництва і процесів, вони зазвичай знижують витрати на обслуговування. Новітні системи розумного моніторингу забезпечують значні переваги з погляду управління ризиками та зниження кількості помилок у роботі обладнання.

Аналіз останніх досліджень і публікацій. Для підготовки иієї статті були проаналізовані різні загальнодоступні дані, експериментальні рішення, а також висновки інших експериментів для створення бази знань з иієї теми дослідження.

Виділення недосліджених частин загальної проблеми. Різні технології моніторингу від різних постачальників технологій автоматизаиії можуть працювати онлайн і офлайн. Цієї статті недостатньо, щчоб описати всі з них.

Постановка завдання. У иій статті автоматизовані системи моніторингу було проаналізовано з точки зору проблем огляду механізмів та профілактичного обслуговування. Результати статті є основою для подальшого дослідження проблеми.

Виклад основного матеріалу. Щоб передбачити майбутню несправність або запобігти виходу з ладу промислового обладнання зараз, необхідно впровадити новітні технології моніторингу. Використання компактних рішень розумного моніторингу, таких як Mitsubishi SCM або VIKON MMP, забезпечує хорошу основу для вирішення таких проблем, як наприклад, несправність підшипника та його подальший вихід з ладу.

Висновки відповідно до статті. Ця стаття показує можливості розумного моніторингу системи промислової автоматизачії. Протестована система може надати корисну інформачію про невідомі умови всередині намого пристрою, не перериваючи роботу.

Ключові слова: моніторинг; обслуговування; автоматизачія.

Рис.: 9. Табл.: 1. Бібл.: 9.

Róbert Rákay - Assistent Professor, Ph.D. of technical sciences, Technical University of Kosice (Letná 9, 04200, Košice, Slovak Republic).

E-mail: robert.rakay@tuke.sk

ORCID: https://orcid.org/0000-0002-7151-3749

Scopus Author ID: 56922070700

Alena Galajdová -Head of the Department, professor, Ph.D. of technical sciences, Technical University of Kosice (Letna 9, 04200, Košice, Slovak Republic).

E-mail: alena.galajdova@tuke.sk

ORCID: https://orcid.org/0000-0003-0128-4191

Scopus Author ID: 6506796741 